\title{
Evaluation of Water Melon Peels as Economic Adsorbents for Removal of High Levels of Iron from Different Water Sources
}

\author{
Hassouna MEM${ }^{1 *}$, Marzouk MA², Elbably MA ${ }^{3}$ and El Maghrabi AH $^{1}$ \\ ${ }^{1}$ Department of Chemistry, Beni-Suef University, Egypt \\ ${ }^{2}$ Department of Botany \& Microbiology, Beni-Suef University, Egypt \\ ${ }^{3}$ Department of Hygiene, Management \& Zoonoses, Beni-Suef University, Egypt
}

Submission: November 19, 2018; Published: March 08, 2019

*Corresponding author: Hassouna MEM, Department of Chemistry, Faculty of Science, Beni-Suef University, Egypt

\begin{abstract}
Optimum conditions for the adsorption of iron onto crude and modified (with lactic acid and tri sodium citrate) water melons peels (WMP) from aqueous solution are investigated as inexpensive and eco-friendly available adsorbents. Water samples are gathered from different sources (surface, tap and ground). The three WMP forms are characterized by FT-IR and SEM. Adsorption variables such as: adsorbent dose, stirring time and $\mathrm{pH}$ have been optimized. The removal efficiency of the unmodified WMP reaches its maximum uptake in the pH range 4-6, the other modified WMP powders in the range 5-7. The removal process is slow in the first $10 \mathrm{~min}$. then it is gradually increased till equilibrium after $20 \mathrm{~min}$ in case of unmodified WMP, the two modified forms reach equilibrium after $15 \mathrm{~min}$. Kinetic studies indicated that adsorption follows the Langmuir and Freundlich adsorption isotherms. Desorption processes assured the possibility to regenerate and reuse the adsorbents.
\end{abstract}

Keywords: Heavy metals; Fe; Water melon peels; Economic sorbent; Water sources; Adsorption

\section{Introduction}

Heavy metals have become a question of global concern considering their hard consequences which requires ongoing evaluation and revision of water resource policy at all standard international levels down to individual aquifers and wells [1,2]. Their main sources include wastewater discharged from health facilities [3], other industries, metal plating and alloy manufacturing $[4,5]$. The technological advancement in electronic industry is posing a new environmental challenge in the form of electronic waste, the electronic devices after their disposal into the soil are not processed properly which result in the accumulation of the toxic metals in the soil [6]. Heavy metals present in the wastewater are persistent and non-degradable in nature [7]. Presence of these metals in waste stream and ground water is one of the most environmental concerns since these metal ions are toxic to various life forms especially if their concentration is more than the accepted limit $[8,9]$. For the elimination of dissolved heavy metal ions, literature [10] is full of techniques that have been performed such as solvent extraction, ion exchange, membrane process, electro dialysis, precipitation, phytoextraction, ultra-filtration, reverse osmosis and adsorption. These methods, generally, are of high cost with troubles such as incomplete metal removal, high reagent consumption, energy requirements and generation of toxic sludge or other waste products that need further disposal or treatment [11]. Iron is commonly found in rocks and soil. Under suitable conditions, iron will leach into water resources. Iron concentration greater than $0.3 \mathrm{mg} / \mathrm{L}$ causes water staining that negatively affects plumbing fixtures dishware and clothes and produce a yellow to reddish color in water appearance. These levels may also change the taste and odor of drinking water. This led many investigators to search for inexpensive substitutes such as zeolites, silica gel, chitosan, clay materials and agricultural wastes $[12,13]$. The adsorption technique remains the more favorable method because of its high capacity and low cost. During the past few years, several research articles were published reporting the successful use of different kinds of agricultural wastes for the removal of metal ions from aqueous solutions [14-17]. Such as Acacia leucocephala bark powder [18], Moringa oleifera bark (MOB) [19], cork waste biomass [20,21] rice straw [22], sugarcane bagasse waste [23,24], garden grass (GG) [25], castor leaf powder [26], green bean husk (GBH) [27], ficus carcia leaves [28], Avenafatua biomass [29]. Fruit peels have been extensively used [30-34] for the 
same purpose including banana (Musa paradisiaca), lemon (Citrus limonum) and orange (Citrus sinensis) peels [35]. The present study has been carried out to investigate the possibility of the use of peels of water melons (Citrullus vulgaris) (WMP) powder as an effective and efficient agricultural solid waste byproduct for the removal of iron ions from aqueous solutions.

\section{Materials and Methods}

\section{Chemicals}

Ferrous ammonium sulphate (Aldrich), Hydrochloric acid (BDH), 1, 10 Phenanthroline (Aldrich) (0.2\%) solution of phenanthroline hydrochloride or hydrate (phen.) in $0.1 \mathrm{M} \mathrm{HCl}$, Tri sodium citrate (Aldrich) and Hydroxylamine hydrochloride (Aldrich).

\section{Reagents}

a) Standard Iron (II) solution (1000 ppm) Fe (II) stock solution was prepared by dissolving $0.7016 \mathrm{~g}$ of ammonium ferrous sulphate $\left(\mathrm{NH}_{4}\right)_{2} \mathrm{SO}_{4} \cdot \mathrm{FeSO}_{4} \cdot 6 \mathrm{H}_{2} \mathrm{O}$, (Aldrich, USA) in DDW containing $5 \mathrm{~mL}$ conc. $\mathrm{H}_{2} \mathrm{SO}_{4}$ and accurately dilute to volume in $100 \mathrm{~mL}$ volumetric flask.

b) 1,10 Phenanthroline (0.2\%) Phenanthroline hydrochloride or hydrate (phen), in $100 \mathrm{~mL}$ volumetric flask $0.2 \mathrm{gm}$ of phenanthroline are dissolved in doubly distilled water (DDW) and diluted to the mark with $0.1 \mathrm{M} \mathrm{HCl}$.

c) Tri sodium citrate $(10 \%)$ solution in $100 \mathrm{~mL}$ volumetric flask, $10 \mathrm{~g}$ of tri sodium citrate are dissolved in doubly distilled water (DDW) and dilute to the mark.

d) Hydroxylamine hydrochloride (10 \%): $10 \mathrm{~g}$ of hydroxylamine- $\mathrm{HCl}$ are dissolved in DDW and diluted to $100 \mathrm{~mL}$.

\section{Preparation of the WMP powder and its modified forms}

\section{Preparation of the WMP powder}

Water melon peels (WMP) are collected from the agricultural Egyptian fields. The white part of peels is cut, washed, air dried and then are finely powdered in a mixer till being near the nano size. The final product is applied as the crude peels powder for the removal of iron from water samples according to the proposed procedure.

\section{Lactic Acid Modified (WMP) powder}

$100 \mathrm{~g}$ of the crude (WMP) powder are refluxed with $500 \mathrm{~mL}$ of $0.5 \mathrm{M}$ lactic acid solution over a boiling water bath for $6 \mathrm{~h}$. The produced precipitate is separated, repeatedly washed with DDW till free from acid then dried in an oven at $60^{\circ} \mathrm{C}$ for two hrs. After cooling in a desiccator to room temperature, it is finely grinded once again.

\section{Tri sodium citrate Modified WMP powder}

$100 \mathrm{~g}$ of the crude (WMP) are, similarly, refluxed with $500 \mathrm{~mL}$ of $0.5 \mathrm{M}$ tri sodium citrate solution over a boiling water bath for $6 \mathrm{~h}$. The produced precipitate is, similarly, separated, washed, dried and grinded.

\section{Instruments}

UV/Vis. Spectrophotometer (Shimadzu UV/Vis. Perkin Elemer Lambada 3B Spectrophotometer using $1 \mathrm{~cm}$ Quartz cell is applied to determine the concentration of the residual iron ions in the effluents after the application of the adsorption processes); Flame Atomic Absorption Spectrophotometer AA 240FS, Agilent Technologies, applied for the rapid and confirmation determination of the concentration of iron ions; $\mathrm{pH}$ meter (The $\mathrm{pH}$ measurements are carried by using the microprocessor $\mathrm{pH}$ meter BT 500 BOECO, Germany, which is calibrated versus two standard buffer solutions at pH4 \& 9 and Mechanical Shaker (with up to 200rpm with speed control was used). The morphologies of the prepared samples and composites are examined using Scanning Electron Microscopy (SEM), FTIR spectroscopy Fourier transform infrared spectra of crude and chemically modified (WMP) powder forms are recorded with a Shimadzu FTIR spectrometer (resolution $4 \mathrm{~cm}^{-1}$ ), equipped with highly sensitive pyroelectric detector (DLATGS). The IR shows the structure morphology, nature of surface hydroxyl groups, and adsorbed $\mathrm{H}_{2} \mathrm{O}$.

\section{Procedure}

\section{Spectrophotometric Determination of Iron}

The remaining iron in the solution is determined spectrophotometrically after reduction to the Fe (II). In a $25 \mathrm{~mL}$ volumetric flask, add $0.5 \mathrm{~mL}$ of the $10 \%$ hydroxylamine solution, $2 \mathrm{~mL} 10 \%$ tri sodium citrate solution and $5 \mathrm{~mL}$ of the standard Fe (II) solution. The $\mathrm{pH}$ is adjusted in the range 3-4. Add $2.5 \mathrm{~mL}$ of $0.2 \% 1,10$ phenanthroline solution, dilute to the mark with DDW and mix thoroughly. After $5 \mathrm{~min}$ the absorbance of the solution is measured at $512 \mathrm{~nm}$ against a blank.

FAA spectrometric method: Flame Atomic Absorption Spectrophotometer is used for the rapid and confirmation determination of the residual concentrations of iron ions after carrying out both the adsorption or the desorption procedures after making appropriate dilutions. The solution is directly measured at $\lambda_{\text {max }}$ equals $372.0 \mathrm{~nm}$ with detection limit of $50 \mu \mathrm{g} / \mathrm{L}$ using a mixture of Acetylene - Nitrous Oxide flame.

\section{Optimization of the Factors Affecting the Adsorption of Iron from Standard Solutions}

\section{Optimization of the $\mathbf{p H}$}

To investigate the effect of $\mathrm{pH}$ on the uptake \% (adsorption) of iron from aqueous media by the crude (WMP) powder, aliquots of $25 \mathrm{~mL}$ containing $20 \mathrm{ppm}$ of the metal ion are transferred to a group of $100 \mathrm{~mL}$ conical flasks each containing $0.1 \mathrm{~g}$ of the crude adsorbent. Adjust the $\mathrm{pH}$ for each flask in the order ranging from $2-10$, respectively by using $0.1 \mathrm{M} \mathrm{NaOH}$ and $\mathrm{HCl}$ solutions and stir for $1 \mathrm{hr}$. Centrifuge the contents of each flask and determine the remaining iron content in the supernatant solution. The sorption percentage of the metal ion by the WMP powder is calculated by equation (1): 


$$
\text { Uptake }(\%)=\left[\left(C_{i}-C_{f}\right) / C_{f}\right] \times 100
$$

Where $\mathrm{C}_{\mathrm{i}}$ and $\mathrm{C}_{\mathrm{f}}$ are the initial and final concentrations of metal ion respectively. Biosorption capacity $\mathrm{q}(\mathrm{mg} / \mathrm{g})$ is calculated by equation (2):

$$
q=\frac{C_{i}-C_{f}}{W t} * V
$$

Where $\mathrm{C}_{\mathrm{i}}$ and $\mathrm{Cf}$ are the initial and final concentrations of iron (ppm), Wt is the dose of sorbents ( $\mathrm{g}$ ) and $\mathrm{V}$ is the volume of solution (mL). The optimum $\mathrm{pH}$ is adjusted to be in the range 4-7. When the same procedure is parallel repeated using the sodium citrate and lactic acid modified powders, the optimum $\mathrm{pH}$ is in the range 5-6 in both cases.

\section{Effect of temperature}

The effect of temperature on the removal of iron ions by the three modified (WMP) powdered forms are studied at different temperatures between 30 and $70^{\circ} \mathrm{C}$.

\section{Sorbent dose}

Aliquots of $25 \mathrm{~mL}$ solution containing $20 \mathrm{ppm}$ iron are transferred to a group of $100 \mathrm{~mL}$ conical flasks. Adjust the $\mathrm{pH}$ for each flask to the optimum value. Varying amounts of the crude (WLP) powder in the range $50-350 \mathrm{mg}$ are added to each flask, respectively. The mixtures are stirred for $1 \mathrm{~h}$. The remaining iron content in supernatant soln. separated by centrifugation is determined spectrophotometrically. The procedure is repeated with the other two (WLP) modified powders.

\section{Contact time}

A set of $100 \mathrm{~mL}$ conical flasks, each of which is uploaded with $0.2 \mathrm{~g}$ of the three (WMP) powder forms and aliquots of $25 \mathrm{~mL}$ solution containing $20 \mathrm{ppm}$ of iron at the optimum $\mathrm{pH}$ and the shaking time is varied for different intervals of time (10-80min) for each flask in its turn, respectively.

\section{Metal ion concentration range}

Applying the optimum conditions of the weight of (WMP) powder, $\mathrm{pH}$ and stirring time in a group of flasks. Aliquots of $25 \mathrm{~mL}$ solution containing varying concentrations of iron ions in the range $10-100 \mathrm{ppm}$ are added to each flask, respectively. The same procedure is applied, and the remaining iron content is determined from which the uptake percent is calculated.

\section{Optimum sample volume}

Different volumes of iron sample in the range from $10-100 \mathrm{~mL}$ are tested.

\section{Results and Discussion}

Bio sorbent production may be an added value to the agrowastes and eventually reduces the agro-wastes management problems over the world. Agro-materials usually have their composition of lignin and cellulose as major constituents and may also include other polar functional groups of lignin, which include al- cohols, aldehydes, ketones, carboxylic, phenolic and ether groups. These groups can bind to some extent heavy metals by donation of an electron pair from these groups to form complexes with the metal ions in solution [36]. During the past few years, several research articles were published reporting the successful use of different kinds of agricultural wastes in the removal of metal ions from aqueous solutions. The use of plant's peels is reported in literature e.g., Ni (II) and Cd (II) removal from aqueous solution on modified plantain peels [8], biosorption of cadmium and nickel by grapefruit peels [34], biosorption of heavy metals present on polluted water by using different waste fruit cortex, banana (Musa paradisiaca), lemon (Citrus limonum) and orange (Citrus sinensis) peel [35], biosorption of aquatic cadmium (II) on unmodified rice straw [21], biosorption on peanut shell [22], equilibrium and kinetics of biosorption of cadmium(II) , copper(II) ions by wheat straw [37] and iron by green clover leaves [38]. Watermelon's botanical name, Citrullus vulgaris, comes from the diminutive form of citrus, referring to the color and shape of the fruit, and vulgaris meaning common or ordinary fruit [39]. Our thinking was forwarded towards trying (WMP) fine powder as a low cost adsorbent for the treatment of a real local problem viz., the existence of iron (and manganese) in the ground water of some wells at El-Wasta, a town which lies $35 \mathrm{Km}$ to the north of Beni-Suef Governorate, Egypt.

\section{Factors that affect the Adsorption Process have been Studied in Details to Improve the Uptake \% of Iron from the Aqueous Solutions}

\section{Optimum pH}

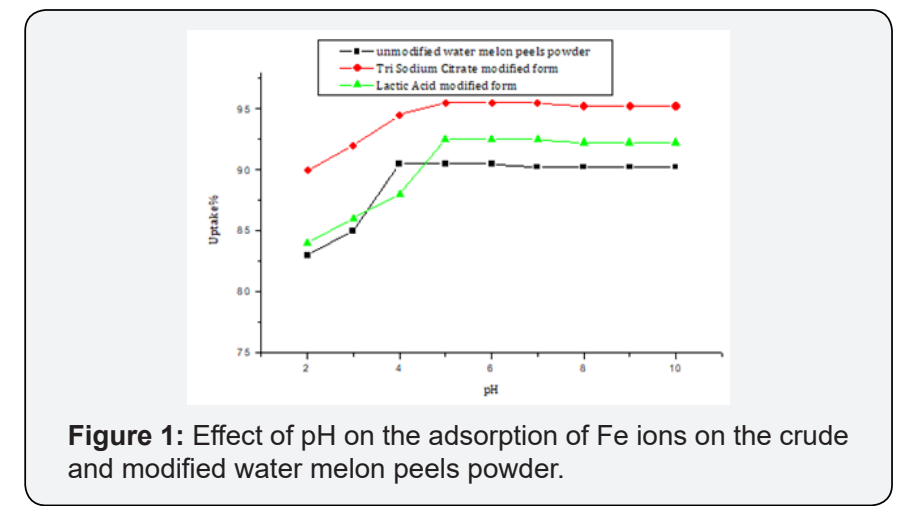

The $\mathrm{pH}$ is directly related to the competition ability of hydrogen ions with metal ions to active sites on the bio sorbent surface. The results indicated low sorption efficiency at low $\mathrm{pH}$ values $(\mathrm{pH}=2-3)$, this was attributed to the high concentration and high mobility of $\mathrm{H}^{+}$, which are preferentially adsorbed instead of metal ions. The removal efficiency of the sorbent is increased by increasing the $\mathrm{pH}$ value until reaches its maximum uptake in the range 4- 6 by the unmodified (WMP). The sodium citrate and lactic acid modified (WMP) powders showed maximum adsorption at the $\mathrm{pH}$ range 5-7. Heavy metal biosorption on the specific and nonspecific bio sorbents is $\mathrm{pH}$ dependent; other researchers found that an increase in adsorption is a result of increasing the $\mathrm{pH}$ of the solution (Figure 1, Table 1). 


\section{International Journal of Environmental Sciences \& Natural Resources}

Table 1: Effect of $\mathrm{pH}$ on the adsorption of $\mathrm{Fe}$ ions on crude and modified water melon peels powders.

\begin{tabular}{|c|c|c|c|c|c|c|}
\hline & \multicolumn{2}{|c|}{ Crude Form } & \multicolumn{2}{c|}{ Lactic Acid Form } & \multicolumn{2}{c|}{ Trisodium Citrate Form } \\
\hline $\mathbf{p H}$ & Std. Deviation* & Recovery \% & Std. Deviation* & Recovery \% & Std. Deviation* & Recovery \% \\
\hline 2.00 & 0.1000 & $83.10 \pm 0.0577$ & 0.1527 & $84.16 \pm 0.0882$ & 0.2000 & $90.20 \pm 0.1155$ \\
\hline 3.00 & 0.2082 & $85.23 \pm 0.1202$ & 0.2000 & $86.20 \pm 0.1155$ & 0.1527 & $92.13 \pm 0.0882$ \\
\hline 4.00 & 0.1527 & $90.53 \pm 0.0882$ & 0.1527 & $88.13 \pm 0.0882$ & 0.1527 & $94.46 \pm 0.0882$ \\
\hline 5.00 & 0.1000 & $90.60 \pm 0.0577$ & 0.1527 & $92.46 \pm 0.0882$ & 0.1527 & $95.53 \pm 0.0882$ \\
\hline 6.00 & 0.1527 & $90.33 \pm 0.0882$ & 0.2000 & $92.30 \pm 0.1155$ & 0.2082 & $95.43 \pm 0.1202$ \\
\hline 7.00 & 0.0153 & $90.23 \pm 0.0088$ & 0.2311 & $93.93 \pm 0.7705$ & 0.1527 & $95.46 \pm 0.0882$ \\
\hline 8.00 & 0.0100 & $90.25 \pm 0.0058$ & 0.0200 & $92.25 \pm 0.0115$ & 0.0200 & $95.25 \pm 0.0115$ \\
\hline 9.00 & 0.0153 & $90.25 \pm 0.0088$ & 0.0321 & $92.26 \pm 0.0186$ & 0.0289 & $95.26 \pm 0.0167$ \\
\hline 10.00 & 0.0153 & $90.25 \pm 0.0088$ & 0.0100 & $92.24 \pm 0.0058$ & 0.0252 & $95.25 \pm 0.0145$ \\
\hline
\end{tabular}

\section{Effect of temperature}

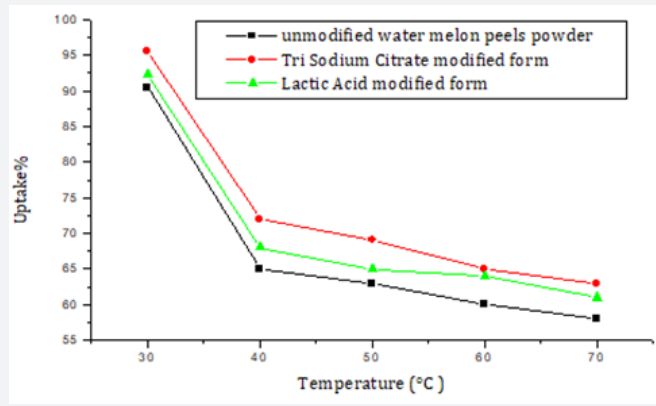

Figure 2: Effect of temperature on the adsorption of Fe ions on the water melon peels powder forms.

Maximum adsorption recovery is obtained at $30{ }^{\circ} \mathrm{C}$ for the three adsorbent forms. The uptake percentage decreased with the increase in temperature suggesting that the adsorption process is exothermic [40]. As observed in (Figure 2, Table 2), tri sodium ci- trate modified form gave better adsorption performance than the crude and lactic acid forms. These results also proved that during the adsorption process, no permanent chemical bonds are formed [41].

Table 2: Effect of temperature on the adsorption of Fe ions on the crude and modified water melon peels powders.

\begin{tabular}{|c|c|c|c|c|c|c|}
\hline & \multicolumn{2}{|c|}{ Crude Form } & \multicolumn{2}{c|}{ Lactic Acid Form } & \multicolumn{2}{c|}{ Trisodium Citrate Form } \\
\hline Temperature ${ }^{\circ}$ C & Std. Deviation* & Recovery \% & Std. Deviation* & Recovery \% & Std. Deviation* & Recovery \% \\
\hline 30.00 & 0.1000 & $90.60 \pm 0.0577$ & 0.0153 & $92.25 \pm 0.0088$ & 0.1000 & $95.60 \pm 0.0577$ \\
\hline 40.00 & 0.1527 & $65.16 \pm 0.0882$ & 0.1732 & $68.20 \pm 0.1000$ & 0.1527 & $72.13 \pm 0.0882$ \\
\hline 50.00 & 0.0577 & $63.06 \pm 0.0333$ & 0.1000 & $65.10 \pm 0.0577$ & 0.1527 & $69.16 \pm 0.0882$ \\
\hline 60.00 & 0.1527 & $60.16 \pm 0.0882$ & 0.2082 & $64.23 \pm 0.1202$ & 0.1000 & $65.10 \pm 0.0577$ \\
\hline 70.00 & 0.1527 & $58.16 \pm 0.0882$ & 0.1000 & $61.10 \pm 0.0577$ & 0.1155 & $63.13 \pm 0.0667$ \\
\hline
\end{tabular}

\section{Stirring time}

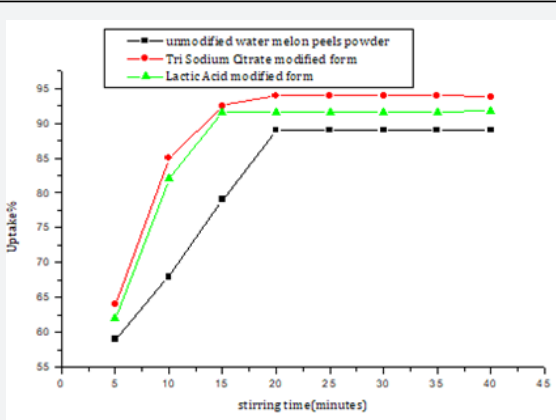

Figure 3: Effect of stirring time on the adsorption of Fe ions on the crude and modified water melon peels powder. 
Equilibrium time is one of the important parameters for selecting a wastewater treatment system [37]. The results show that removal is slow in the first $10 \mathrm{~min}$, then the adsorption $\%$ is gradually increased till equilibrium is reached after $20 \mathrm{~min}$ for the unmodified powder. While both the tri sodium citrate and the lactic acid modified forms attained equilibrium after $15 \mathrm{~min}$. The rate of biosorption seems to pass through two steps, the first one is very rapid surface biosorption, while the second is slow intracellular diffusion (Figure 3, Table 3).

Table 3: Effect of stirring time on the adsorption of Fe ions on the water melon peels powder forms.

\begin{tabular}{|c|c|c|c|c|c|c|}
\hline & \multicolumn{2}{|c|}{ Crude Form } & \multicolumn{2}{c|}{ Lactic Acid Form } & \multicolumn{2}{c|}{ Trisodium Citrate Form } \\
\hline $\begin{array}{c}\text { Stirring time, } \\
\text { min. }\end{array}$ & Std. Deviation* & Recovery \% & Std. Deviation* & Recovery \% & Std. Deviation* & Recovery \% \\
\hline 5.00 & 0.1527 & $59.16 \pm 0.0882$ & 0.1527 & $62.13 \pm 0.0882$ & 0.1000 & $64.10 \pm 0.0577$ \\
\hline 10.00 & 0.1527 & $68.13 \pm 0.0882$ & 0.0321 & $82.02 \pm 0.0186$ & 0.0513 & $85.05 \pm 0.0296$ \\
\hline 15.00 & 0.1000 & $79.10 \pm 0.0577$ & 0.1000 & $91.60 \pm 0.0577$ & 0.0379 & $92.54 \pm 0.0219$ \\
\hline 20.00 & 0.0100 & $89.01 \pm 0.0058$ & 0.0321 & $91.54 \pm 0.0186$ & 0.0100 & $94.01 \pm 0.0058$ \\
\hline 25.00 & 0.0100 & $89.04 \pm 0.0058$ & 0.0208 & $91.55 \pm 0.0120$ & 0.0252 & $94.05 \pm 0.0145$ \\
\hline 30.00 & 0.0153 & $89.07 \pm 0.0088$ & 0.0100 & $91.52 \pm 0.0058$ & 0.0265 & $94.04 \pm 0.0153$ \\
\hline 35.00 & 0.0208 & $89.03 \pm 0.0120$ & 0.0100 & $91.54 \pm 0.0058$ & 0.0493 & $94.03 \pm 0.0285$ \\
\hline 40.00 & 0.0153 & $89.04 \pm 0.0088$ & 0.0265 & $91.53 \pm 0.0153$ & 0.0100 & $94.02 \pm 0.0058$ \\
\hline 45.00 & 0.0321 & $89.03 \pm 0.0186$ & 0.0231 & $91.52 \pm 0.0133$ & 0.0208 & $94.03 \pm 0.0120$ \\
\hline
\end{tabular}

\section{Sorbent dose}

For a specific metal initial concentration, increasing the adsorbent dose provides greater surface area and availability of more active sites, thus leading to the enhancement of metal ion uptake till reach equilibrium [42]. For the unmodified powder, a dose of $0.3 \mathrm{~g}$ sorbent can achieve an uptake of $90.5 \%$ of iron at

Table 4: Effect of sorbent dose on the adsorption of $\mathrm{Fe}$ ions on crude and modified water melon peels powders.

\begin{tabular}{|c|c|c|c|c|c|c|}
\hline \multirow[b]{2}{*}{ Dose g. } & \multicolumn{2}{|c|}{ Crude Form } & \multicolumn{2}{|c|}{ Lactic Acid Form } & \multicolumn{2}{|c|}{ Trisodium Citrate Form } \\
\hline & Std. Deviation* & Recovery \% & Std. Deviation* & Recovery \% & Std. Deviation* & Recovery \% \\
\hline 0.10 & 0.1000 & $70.10 \pm 0.0577$ & 0.1000 & $75.50 \pm 0.0577$ & 0.1527 & $82.16 \pm 0.0882$ \\
\hline 0.15 & 0.2082 & $76.16 \pm 0.1202$ & 0.1527 & $85.13 \pm 0.0882$ & 0.1527 & $87.13 \pm 0.0882$ \\
\hline 0.20 & 0.1000 & $80.10 \pm 0.0577$ & 0.1242 & $91.73 \pm 0.7172$ & 0.1000 & $95.40 \pm 0.0577$ \\
\hline 0.25 & 0.1527 & $85.16 \pm 0.0882$ & 0.1155 & $92.43 \pm 0.0667$ & 0.1527 & $95.33 \pm 0.0882$ \\
\hline 0.30 & 0.1000 & $90.60 \pm 0.0577$ & 0.1000 & $92.60 \pm 0.0577$ & 0.2000 & $95.30 \pm 0.1154$ \\
\hline 0.35 & 0.1732 & $90.60 \pm 0.1000$ & 0.1732 & $92.60 \pm 0.1000$ & 0.2646 & $95.30 \pm 0.1527$ \\
\hline 0.40 & 0.1000 & $90.50 \pm 0.0577$ & 0.1527 & $92.53 \pm 0.0882$ & 0.1000 & $95.40 \pm 0.0577$ \\
\hline 0.45 & 0.1000 & $90.60 \pm 0.0577$ & 0.1000 & $92.40 \pm 0.0577$ & 0.1000 & $95.60 \pm 0.0577$ \\
\hline 0.50 & 0.1155 & $90.43 \pm 0.0667$ & 0.1527 & $92.46 \pm 0.0882$ & 0.0577 & $95.53 \pm 0.0333$ \\
\hline
\end{tabular}


Initial metal ion concentration

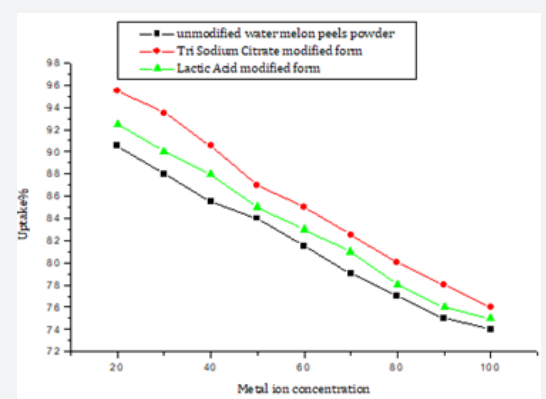

Figure 5: Effect of metal ion concentration on the adsorption of Fe ions on the crude and modified water melon peels powders.

The initial metal ion concentration does a substantial force to diffuse to the sorbent surface by intra particle diffusion. The to overcome all mass transfer resistances of the metal ions be- maximum metal uptake was $90.5 \%$ in the case of the unmodified tween aqueous and solid phase [43]. At lower concentrations the (WMP) powder, 92.5\% for lactic acid modified one and 95.5\% in adsorption sites utilize the available metal ion more rapidly in the case of tri sodium citrate form at metal ion concentration of 20 comparison to higher concentrations where the metal ions need ppm, (Figure 5, Table 5).

Table 5: Effect of metal ion concentration on the adsorption of Fe ions on crude and modified water melon peels powders.

\begin{tabular}{|c|c|c|c|c|c|c|}
\hline & \multicolumn{2}{|c|}{ Crude Form } & \multicolumn{2}{c|}{ Lactic Acid Form } & \multicolumn{2}{c|}{ Trisodium Citrate Form } \\
\hline Metal Conc. ppm & Std. deviation* & Recovery \% & Std. Deviation* & Recovery \% & Std. Deviation* & Recovery \% \\
\hline 20.00 & 0.1000 & $90.60 \pm 0.0577$ & 0.1000 & $92.40 \pm 0.0577$ & 0.1000 & $95.50 \pm 0.0577$ \\
\hline 30.00 & 0.1527 & $88.13 \pm 0.0882$ & 0.1000 & $90.10 \pm 0.0577$ & 0.1000 & $93.50 \pm 0.0577$ \\
\hline 40.00 & 0.1000 & $85.40 \pm 0.0577$ & 0.1527 & $88.13 \pm 0.0882$ & 0.1000 & $90.60 \pm 0.0577$ \\
\hline 50.00 & 0.1000 & $84.10 \pm 0.0577$ & 0.1527 & $85.16 \pm 0.0882$ & 0.1000 & $87.10 \pm 0.0577$ \\
\hline 60.00 & 0.1527 & $81.33 \pm 0.0882$ & 0.2000 & $83.20 \pm 0.0509$ & 0.1527 & $85.16 \pm 0.0882$ \\
\hline 70.00 & 0.2517 & $79.03 \pm 0.1453$ & 0.1000 & $81.00 \pm 0.0577$ & 0.1000 & $82.60 \pm 0.0577$ \\
\hline 80.00 & 0.1527 & $77.16 \pm 0.0882$ & 0.1000 & $78.10 \pm 0.0577$ & 0.1000 & $80.10 \pm 0.0577$ \\
\hline 90.00 & 0.1527 & $75.16 \pm 0.0882$ & 0.1527 & $76.13 \pm 0.0882$ & 0.1527 & $78.16 \pm 0.0882$ \\
\hline 100.00 & 0.1000 & $90.60 \pm 0.0577$ & 0.1527 & $75.16 \pm 0.0882$ & 0.2082 & $76.23 \pm 0.1202$ \\
\hline
\end{tabular}

\section{Sample volume}

Table 6: Effect of sample volume on the adsorption of Fe ions on the crude and modified water melon peels powders.

\begin{tabular}{|c|c|c|c|c|c|c|}
\hline & \multicolumn{2}{|c|}{ Crude Form } & \multicolumn{2}{c|}{ Lactic Acid Form } & \multicolumn{2}{c|}{ Trisodium Citrate Form } \\
\hline Sample Vol. mL & Std. Deviation* & Recovery \% & Std. Deviation* & Recovery \% & Std. Deviation* & Recovery \% \\
\hline 25.00 & 0.1000 & $90.60 \pm 0.0577$ & 0.1000 & $92.60 \pm 0.0577$ & 0.1000 & $95.60 \pm 0.0577$ \\
\hline 50.00 & 0.1000 & $89.60 \pm 0.0577$ & 0.1000 & $92.10 \pm 0.0577$ & 0.1000 & $94.60 \pm 0.0577$ \\
\hline 75.00 & 0.1000 & $88.60 \pm 0.0577$ & 0.1154 & $91.56 \pm 0.0667$ & 0.1527 & $93.53 \pm 0.0882$ \\
\hline 100.00 & 0.1527 & $88.13 \pm 0.0882$ & 0.2081 & $91.23 \pm 0.1202$ & 0.1000 & $92.50 \pm 0.0577$ \\
\hline 125.00 & 0.2081 & $88.23 \pm 0.1202$ & 0.1000 & $90.60 \pm 0.0577$ & 0.1000 & $92.10 \pm 0.0577$ \\
\hline 150.00 & 0.1000 & $88.10 \pm 0.0577$ & 0.1732 & $90.60 \pm 0.1000$ & 0.2309 & $92.13 \pm 0.1333$ \\
\hline 175.00 & 0.1527 & $88.16 \pm 0.0882$ & 0.1000 & $90.50 \pm 0.0577$ & 0.1527 & $92.13 \pm 0.0882$ \\
\hline 200.00 & 0.2081 & $88.16 \pm 0.1202$ & 0.1732 & $90.60 \pm 0.1000$ & 0.2886 & $92.17 \pm 0.1667$ \\
\hline 225.00 & 0.1527 & $88.16 \pm 0.0882$ & 0.1000 & $90.60 \pm 0.0577$ & 0.1000 & $92.10 \pm 0.0577$ \\
\hline 250.00 & 0.1000 & $88.10 \pm 0.0577$ & 0.0577 & $90.53 \pm 0.0333$ & 0.0577 & $92.03 \pm 0.0333$ \\
\hline
\end{tabular}

At optimum conditions the volume of $25 \mathrm{~mL}$ achieved the best from the Table 6 , it is clear that iron removal percentage decreases adsorption percentage with all tested (WMP) powders. It is clear with the increase of the volume. 


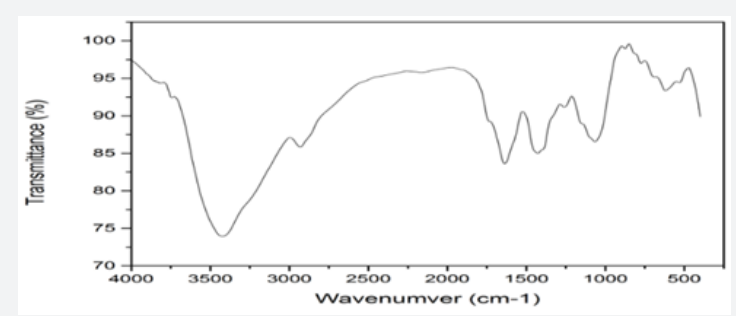

Figure 6: FTIR Spectrum of crude water melons peels powder in the Range $500-4000 \mathrm{~cm}^{-1}$.

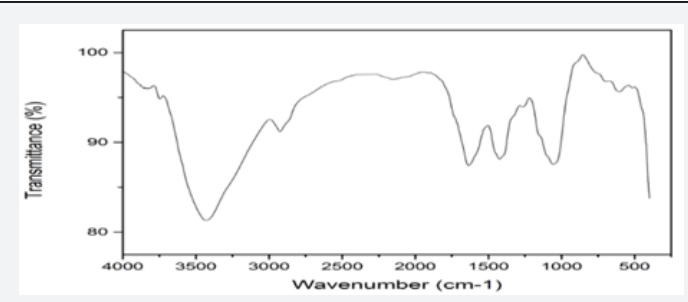

Figure 7: FTIR Spectrum of adsorbent tri sodium citrate water melons peels powder form in the Range $500-4000 \mathrm{~cm}-1$.

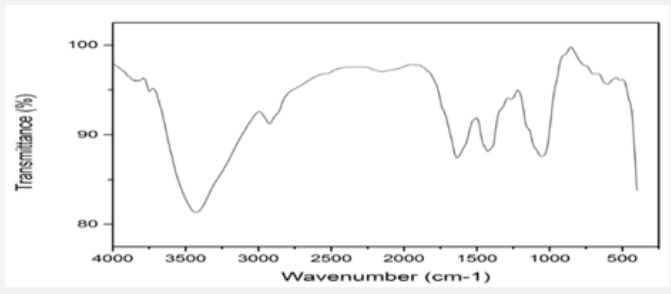

Figure 8: FTIR Spectrum of Adsorbent lactic acid water melons peels powder form in the Range $500-4000 \mathrm{~cm}-1$.

\section{Characterization of used adsorbents}

The composition and topography of the studied adsorbents have been characterized by FT-IR and SEM.

Infra-red spectroscopy: Figure $9 \& 10$ adepicts the FT-IR spectrum of the unmodified (WMP) powder form. The broad band in the region around $3425 \mathrm{~cm}^{-1}$ is specific to the surface hydroxyl groups of bonded carboxylic acid. The $\mathrm{O}-\mathrm{H}$ stretching vibrations occurred within a broad range of frequencies indicating the presence of free hydroxyl groups and bonded $\mathrm{O}-\mathrm{H}$ bands of carboxylic acid, the $-\mathrm{OH}$ carbonyl and carboxylic groups have been reported as very important sorption sites for metal ions. The asymmetric $\mathrm{C}-\mathrm{H}$ stretching of surface methyl groups usually present on the lignin structure is observed at $2900 \mathrm{~cm}^{-1}$. The characteristic peaks because of the $\mathrm{C}-\mathrm{O}$ group in carboxylic and alcoholic groups are present at $1053 \mathrm{~cm}^{-1}$ [44]. The ionization of both the carboxylic acid and hydroxyl functional groups present in the structure of the adsorbent can be achieved by deprotonation that allowing it to interact with metals more easily and therefore provides the major biosorption sites for the removal of iron ions from solutions [44]. A broadening peak at around $1650 \mathrm{~cm}^{-1}$ due to carbonyl group peak is observed. This indicates the involvement of both the hydroxyl and carbonyl groups in the adsorption of iron. Figure 7 the presence of COO- of the carboxylate can be attributed to the peak positions at $1452.30 \mathrm{~cm}^{-1}$ and $1400.22 \mathrm{~cm}^{-1}$. Alkyl chains around are observed at $2920-2850 \mathrm{~cm}^{-1}$. The peaks in range $1000-1200 \mathrm{~cm}^{-1}$ symbolize C-C and C-O stretching.
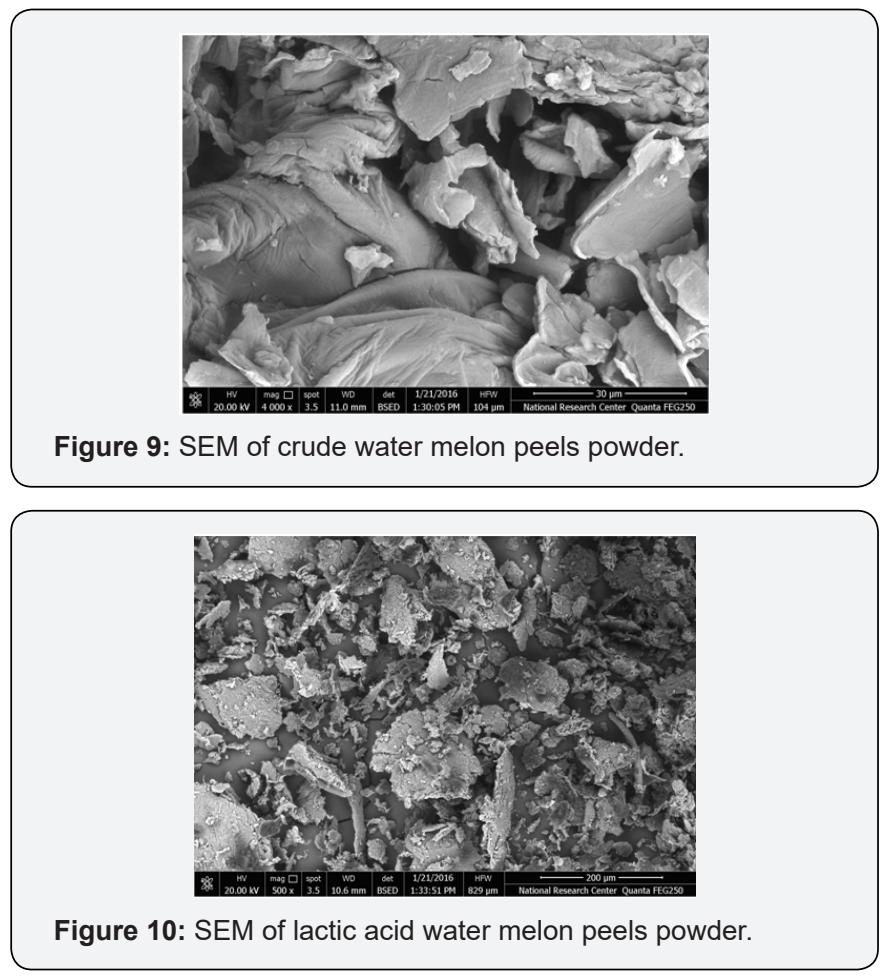

The Morphologies of the prepared adsorbents

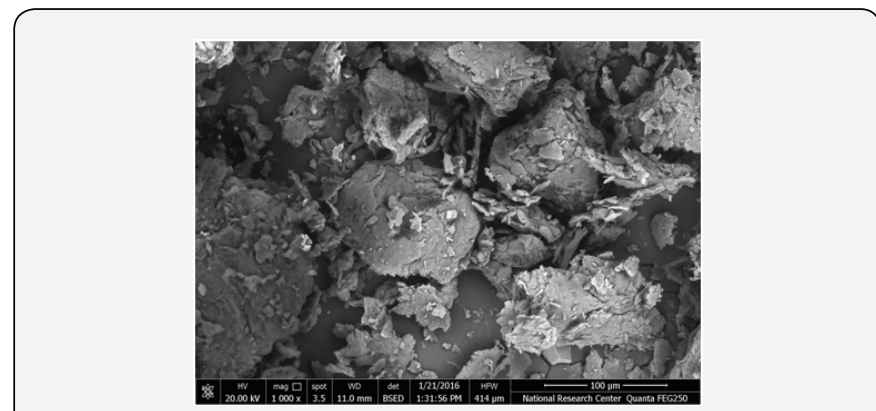

Figure 11: SEM of tri sodium citrate water melon peels powder.

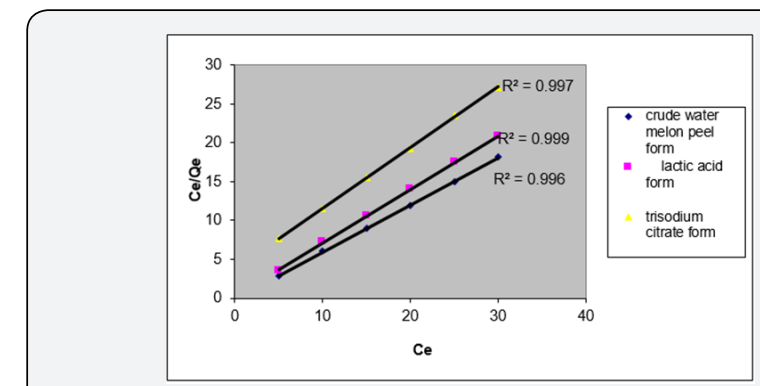

Figure 12: Langmuir isotherm plots for the adsorption of iron ions by water melon peels powders.

This study revealed the micro porous structure of the adsorbent. The SEM micrographs of (WMP) are as shown in Figures 9-11. The micrographs showed that the bio sorbent has 
a smoothening and irregular surface (Figure 9). A significant change in the bio sorbent surface is observed after the modification (Figure 11\&12). A rough effect is perceived in (Figure 12) It is observed as providing a large area for ion-surface interaction. Different surface shapes of the bio sorbent may be due to its modification with lactic acid and tri sodium citrate.

\section{Selectivity of the adsorbent}

Adsorption studies applying the three adsorbents under investigation, proved that they are nonselective towards different heavy metals that may be present in wastewaters as pollutants. However, the non-selectivity of such types of adsorbents is frequent in the literature; their tolerance is attributed to being low cost and available. Current work in our laboratory is devoted for the development and applications of selective and low-cost adsorbent.

\section{Adsorption isotherm studies}

For solid-liquid adsorption system, the adsorption behavior can well be described as adsorption isotherm model, the adsorption isotherm meaning the distribution of adsorbate molecules among the solid phase and the liquid phase at equilibrium. Equilibrium is said to be reached when the concentration of adsorbate in bulk solution is in dynamic balance with that on the liquid adsorbate interface. It is significant to study the adsorption behavior in order to describe adsorption process using appropriate adsorption isotherm model.

\section{Langmuir adsorption isotherm}

The Langmuir isotherm model assumes a surface with homogeneous binding sites, equivalent sorption energies, and no interaction between the sorbet species [45]. The equilibrium adsorption data for the concentrations of iron ions is fitted into the linear form of Langmuir's isotherm equation, to determine the distribution of iron ions between the adsorbent and solution according to equation (3):

$$
\frac{C_{e}}{Q_{e}}=\frac{1}{Q_{m} K_{L}}+\frac{C_{e}}{Q_{e}}(3)
$$

Where $\mathrm{C}_{\mathrm{e}}$ is the concentration of the iron ions in solution (mg $\left.L^{-1}\right), Q_{e}$ is the equilibrium concentration of iron ions on (WMP) adsorbent $\left(\mathrm{mg} \mathrm{g}^{-1}\right), \mathrm{Q}_{\mathrm{m}}$ and $\mathrm{K}_{\mathrm{L}}$ are Langmuir constants related to sorption capacity and the rate of adsorption respectively. Maximum adsorption capacity $\left(Q_{m}\right)$ is the monolayer capacity of the adsorbent $\left(\mathrm{mg} \mathrm{g}^{-1}\right)$ and $\mathrm{K}_{\mathrm{L}}$ is the Langmuir adsorption constant. A plot of $\mathrm{C}_{\mathrm{e}} / \mathrm{Q}_{\mathrm{e}}$ against Ce over the entire concentration range is a straight line with a slope of $1 / Q_{m}$ and the intercept of $1 / Q_{m} K_{L}$. The correlation coefficient $\left(R_{2}\right)$ values reported are very close to 1 indicating that the adsorption follows the Langmuir adsorption isotherm. The quality of Langmuir isotherm can be determined by the magnitude of a dimensionless constant $\mathrm{R}_{\mathrm{L}}$ known as the separation factor expressed in equation (4):

$$
R_{L}=\frac{1}{1+C_{0} R_{L}}(4)
$$

where $\mathrm{C}_{\mathrm{o}}$ is the initial concentration of the iron ions in $\mathrm{mg} \mathrm{L}^{-1}$ and $\mathrm{K}_{\mathrm{L}}$ is the Langmuir constant described earlier. The adsorption process is favorable within the range $0<\mathrm{R}_{\mathrm{L}}<1$, unfavorable when $\mathrm{R}_{\mathrm{L}}>1$, becomes linear when $\mathrm{R}_{\mathrm{L}}=1$, and the process is irreversible when $R_{L}=0$. The value of RL for crude WMP is 0.0475 and for forms modified with tri sodium citrate and lactic acid equal to 0.0408 and 0.0460 respectively; hence the adsorption process is favorable (Figure 13, Table 7).

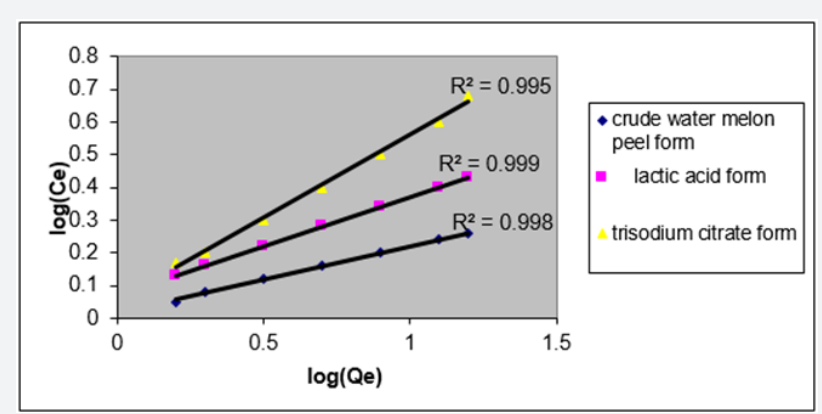

Figure 13: Freundlich isotherm plots for the adsorption of iron ions by water melon peels powder.

Table 7: Langmuir and Freundlich adsorption isotherm Parameters.

\begin{tabular}{|c|c|c|c|c|c|c|c|}
\hline \multicolumn{5}{|c|}{ Langmuir and Freundlich Adsorption Isotherm Parameters of Iron Ions by Water Melon Peel Forms } \\
\hline & \multicolumn{3}{|c|}{ Langmuir Isotherm Parameters } & \multicolumn{3}{c|}{ Freundlich Isotherm Parameters } \\
\hline S./No & $\begin{array}{c}\text { Unmodified } \\
\text { water melon } \\
\text { peels powder }\end{array}$ & $\begin{array}{c}\text { Tri sodium ci- } \\
\text { trate modified } \\
\text { form }\end{array}$ & $\begin{array}{c}\text { Lactic acid } \\
\text { modified form }\end{array}$ & $\begin{array}{c}\text { Unmodified } \\
\text { water melon } \\
\text { peels powder }\end{array}$ & $\begin{array}{c}\text { Tri sodium ci- } \\
\text { trate modified } \\
\text { form }\end{array}$ & $\begin{array}{c}\text { Lactic acid } \\
\text { modified form }\end{array}$ \\
\hline 1 & $\mathrm{Q}_{\max }(\mathrm{mg} / \mathrm{g})$ & 90 & 97 & 93 & 0.471 & 0.288 & 0.311 \\
\hline
\end{tabular}




\section{International Journal of Environmental Sciences \& Natural Resources}

\begin{tabular}{|l|l|l|l|l|l|l|l|}
\hline 2 & $\mathrm{~K}_{\mathrm{L}}$ & 1.002 & 1.174 & 1.035 & 0.796 & 0.958 & 0.899 \\
\hline 3 & $\mathrm{R}_{2}$ & 0.996 & 0.997 & 0.999 & 0.998 & 0.995 & 0.999 \\
\hline 4 & $\mathrm{R}_{\mathrm{L}}$ & 0.047 & 0.041 & 0.046 & & & \\
\hline
\end{tabular}

\section{Freundlich adsorption isotherm}

The Freundlich isotherm model applies to adsorption on heterogeneous surfaces with the interaction between adsorbed molecules, and the application of the Freundlich equation also suggests that sorption energy exponentially decreases on completion of the sorption centers of an adsorbent [28]. The linear form of the Freundlich adsorption Model equation (5):

$$
\log Q_{e}=\log _{e} K_{F}+\frac{1}{n} \log _{e} C_{e}(5)
$$

Where $Q_{e}$ is the amount of iron ions adsorbed at equilibrium per gram of the adsorbent $\left(\mathrm{mg} \mathrm{g}^{-1}\right), \mathrm{C}_{\mathrm{e}}$ is the equilibrium concentration of the iron ions in the solution $\left(\mathrm{mg} \mathrm{L}^{-1}\right)$, and $\mathrm{K}_{\mathrm{f}}$ and $\mathrm{n}$ are the Freundlich adsorption model constants related to the adsorption capacity and adsorption intensity respectively. Loge $\mathrm{Q}_{\mathrm{e}}$ is plotted against loge $\mathrm{C}_{\mathrm{e}}$ and a straight line obtained gave the intercept of $\log \mathrm{K}_{\mathrm{f}}$ and the slope of $1 / \mathrm{n}$. The numerical value of $1 / \mathrm{n}$ reported is less than1, (Figure 13, Table 7).

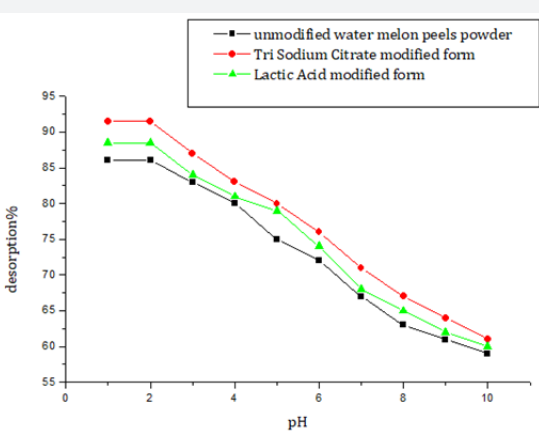

Figure 14:Effect of $\mathrm{pH}$ on desorption of Fe ions on the crude and modified water melon peels Powder.

\section{Analysis of real samples}

Water samples are collected from tap water, Bahr Youssef water, ground water and Ibrahemia (stream)water; samples are subjected to the adsorption procedure as explained previously and the residual iron is analyzed by two methods of finish viz., colorimetry and AAS (Table 8).

Table 8: Concentration of $\mathrm{Fe}(\|)$ in real water samples.

\begin{tabular}{|c|c|c|c|c|c|c|c|c|}
\hline \multirow[b]{2}{*}{$\begin{array}{l}\text { Collected } \\
\text { samples }\end{array}$} & \multirow{2}{*}{$\begin{array}{c}\text { AAS } \\
\begin{array}{c}\text { Found iron } \\
\text { concentra- } \\
\text { tion }\end{array}\end{array}$} & \multirow{2}{*}{$\begin{array}{c}\text { Colorimetry } \\
\begin{array}{c}\text { Found iron } \\
\text { concentra- } \\
\text { tion }\end{array}\end{array}$} & \multicolumn{2}{|c|}{ Crude } & \multicolumn{2}{|c|}{ Lactic acid form } & \multicolumn{2}{|c|}{ Trisodium citrate form } \\
\hline & & & Recovery \% & Recovery \% & $\begin{array}{l}\text { Std. Devia- } \\
\text { tion* }\end{array}$ & Recovery \% & $\begin{array}{l}\text { Std. Devia- } \\
\text { tion* }\end{array}$ & Recovery \% \\
\hline $\begin{array}{l}\text { Drinking } \\
\text { water }\end{array}$ & $3.56 \mathrm{ppm}$ & $3.571 \mathrm{ppm}$ & $\begin{array}{l}89.62 \pm \\
0.0219\end{array}$ & $\begin{array}{l}89.62 \pm \\
0.0219\end{array}$ & 0.03215 & $\begin{array}{l}92.02 \pm \\
0.0185\end{array}$ & 0.0252 & $\begin{array}{l}94.05 \pm \\
0.0145\end{array}$ \\
\hline $\begin{array}{l}\text { Bahr youssef } \\
\text { water }\end{array}$ & $3.20 \mathrm{ppm}$ & $3.211 \mathrm{ppm}$ & $\begin{array}{l}85.01 \pm \\
0.0088\end{array}$ & $\begin{array}{l}85.01 \pm \\
0.0088\end{array}$ & 0.02082 & $\begin{array}{l}90.01 \pm \\
0.0120\end{array}$ & 0.0265 & $\begin{array}{l}92.51 \pm \\
0.0153\end{array}$ \\
\hline Ground water & $4.79 \mathrm{ppm}$ & $4.882 \mathrm{ppm}$ & $\begin{array}{l}86.13 \pm \\
0.0120\end{array}$ & $\begin{array}{l}86.13 \pm \\
0.0120\end{array}$ & 0.01 & $\begin{array}{l}90.58 \pm \\
0.0058\end{array}$ & 0.0493 & $\begin{array}{l}92.11 \pm \\
0.0285\end{array}$ \\
\hline $\begin{array}{l}\text { Ibrahimia } \\
\text { water }\end{array}$ & $1.12 \mathrm{ppm}$ & $1.123 \mathrm{ppm}$ & $\begin{array}{l}87.77 \pm \\
0.0088\end{array}$ & $\begin{array}{l}87.77 \pm \\
0.0088\end{array}$ & 0.05132 & $\begin{array}{l}91.32 \pm \\
0.0296\end{array}$ & 0.01 & $\begin{array}{l}93.53 \pm \\
0.0058\end{array}$ \\
\hline
\end{tabular}

\section{Desorption studies}

Reusability of the adsorbent is tested by regenerating the spent adsorbent following a modified literature procedure [46]. The adsorbed iron ions onto the three WMP surfaces are treated with $25 \mathrm{~mL} 0.1 \mathrm{M} \mathrm{HCl}$ and stirred for $1 \mathrm{~h}$. The amount of iron ions remained in the solution after filtration or centrifugation is measured using the mentioned spectrophotometric and/ the FAAS methods and the percentage desorption $(\mathrm{Rb})$ was calculated relatively to the equation (6):

$$
=\frac{C_{t}}{C_{a}} 100(6) R_{b}
$$

Where $C_{t}$ is the experimental concentration in the solution at time $t$ (ppm), Ca is the adsorbed concentration of sorbate onto the adsorbent surface. 


\section{The Parameters Affecting the Desorption Process are Studied as Illustrated Below}

\section{Effect of pH on desorption of iron}

Table 9: Effect of stirring time on desorption of Fe ions from the crude and modified water melon peels powders.

\begin{tabular}{|c|c|c|c|c|c|c|}
\hline \multirow[b]{2}{*}{$\begin{array}{l}\text { Stirring time, } \\
\text { min. }\end{array}$} & \multicolumn{2}{|c|}{ Crude form } & \multicolumn{2}{|c|}{ Lactic acid form } & \multicolumn{2}{|c|}{ Trisodium citrate form } \\
\hline & Std. Deviation* & Recovery \% & Std. Deviation* & Recovery \% & Std. Deviation* & Recovery \% \\
\hline 5.00 & 0.1000 & $68.10 \pm 0.0577$ & 0.1527 & $72.16 \pm 0.0882$ & 0.1527 & $75.17 \pm 0.0882$ \\
\hline 10.00 & 0.1527 & $71.17 \pm 0.0882$ & 0.1050 & $74.60 \pm 0.0606$ & 0.2248 & $78.25 \pm 0.1202$ \\
\hline 15.00 & 0.1000 & $75.10 \pm 0.0577$ & 0.1000 & $79.10 \pm 0.0577$ & 0.2081 & $82.23 \pm 0.1202$ \\
\hline 20.00 & 0.2081 & $82.07 \pm 0.1202$ & 0.1527 & $82.13 \pm 0.0882$ & 0.1527 & $85.13 \pm 0.0882$ \\
\hline 25.00 & 0.2773 & $85.50 \pm 1.6010$ & 0.2203 & $85.21 \pm 0.1272$ & 0.1527 & $89.13 \pm 0.0882$ \\
\hline 30.00 & 0.0577 & $87.07 \pm 0.0333$ & 0.1000 & $89.10 \pm 0.0577$ & 0.1000 & $92.10 \pm 0.0577$ \\
\hline 35.00 & 0.1000 & $87.10 \pm 0.0577$ & 0.1527 & $89.16 \pm 0.0882$ & 0.2082 & $92.23 \pm 0.1202$ \\
\hline 40.00 & 0.1527 & $87.13 \pm 0.0882$ & 0.1155 & $89.13 \pm 0.0667$ & 0.1527 & $92.13 \pm 0.0882$ \\
\hline 45.00 & 0.1154 & $87.13 \pm 0.0667$ & 0.1527 & $89.17 \pm 0.0882$ & 0.1527 & $92.13 \pm 0.0882$ \\
\hline 50.00 & 0.0577 & $87.07 \pm 0.0333$ & 0.1527 & $89.13 \pm 0.0882$ & 0.2000 & $92.20 \pm 0.1155$ \\
\hline 55.00 & 0.7505 & $87.43 \pm 0.4333$ & 0.2000 & $89.20 \pm 0.1155$ & 0.1527 & $92.16 \pm 0.0882$ \\
\hline 60.00 & 0.0252 & $86.75 \pm 0.0145$ & 0.0153 & $88.74 \pm 0.0088$ & 0.0115 & $91.74 \pm 0.0067$ \\
\hline
\end{tabular}

In strong acidic media at $\mathrm{pH}$ range (1.2-1.9) the three forms of the WMP powder showed high desorption percentages, on in-

creasing the $\mathrm{pH}$ values desorption percentage decreases (Figure 11, Table 9).

\section{Stirring Time}

Table 10: Summary of the optimum conditions for the adsorption of Fe on the crude and modified water melon peels powders.

\begin{tabular}{|c|c|c|c|c|c|c|c|c|c|}
\hline & \multicolumn{3}{|c|}{ Crude Form } & \multicolumn{3}{|c|}{ Lactic Acid Form } & \multicolumn{3}{|c|}{ Trisodium Citrate Form } \\
\hline Parameter & $\begin{array}{l}\text { Optimum } \\
\text { Values }\end{array}$ & $\begin{array}{c}\text { Colorim- } \\
\text { etry } \\
\text { Recovery } \\
\%\end{array}$ & $\begin{array}{c}\text { AAS } \\
\text { Recovery\% }\end{array}$ & $\begin{array}{c}\text { Optimum } \\
\text { Values }\end{array}$ & $\begin{array}{c}\text { Colorim- } \\
\text { etry } \\
\text { Recovery } \\
\%\end{array}$ & $\begin{array}{c}\text { AAS } \\
\text { Recovery\% }\end{array}$ & $\begin{array}{l}\text { Optimum } \\
\text { Values }\end{array}$ & $\begin{array}{c}\text { Colorim- } \\
\text { etry } \\
\text { Recovery } \\
\%\end{array}$ & $\begin{array}{c}\text { AAS } \\
\text { Recovery\% }\end{array}$ \\
\hline $\mathrm{pH}$ & $4-6$ & $\begin{array}{l}90.60 \pm \\
0.0577\end{array}$ & $\begin{array}{l}90.53 \pm \\
0.0882\end{array}$ & $5-7$ & $\begin{array}{l}92.46 \pm \\
0.0882\end{array}$ & $\begin{array}{l}92.30 \pm \\
0.1155\end{array}$ & $5-7$ & $\begin{array}{l}95.53 \pm \\
0.0882\end{array}$ & $\begin{array}{l}95.47 \pm \\
0.0882\end{array}$ \\
\hline $\begin{array}{l}\text { Shaking } \\
\text { time, min }\end{array}$ & $20 \mathrm{~min}$ & $\begin{array}{l}89.01 \pm \\
0.0058\end{array}$ & $\begin{array}{l}89.03 \pm \\
0.0120 \\
\end{array}$ & $15 \mathrm{~min}$ & $\begin{array}{l}91.60 \pm \\
0.0577\end{array}$ & $\begin{array}{l}91.54 \pm \\
0.0058\end{array}$ & $20 \mathrm{~min}$ & $\begin{array}{l}94.01 \pm \\
0.0058\end{array}$ & $\begin{array}{l}94.02 \pm \\
0.0058\end{array}$ \\
\hline $\begin{array}{l}\text { Metal con- } \\
\text { centration }\end{array}$ & $20 \mathrm{ppm}$ & $\begin{array}{l}90.60 \pm \\
0.0577\end{array}$ & $\begin{array}{l}90.40 \pm \\
0.0366\end{array}$ & $20 \mathrm{ppm}$ & $\begin{array}{l}92.40 \pm \\
0.0577\end{array}$ & $\begin{array}{l}92.50 \pm \\
0.0666\end{array}$ & $20 \mathrm{ppm}$ & $\begin{array}{l}95.50 \pm \\
0.0577\end{array}$ & $\begin{array}{l}95.46 \pm \\
0.0033\end{array}$ \\
\hline $\begin{array}{c}\text { Sorbent } \\
\text { dose }\end{array}$ & $0.3 \mathrm{~g}$ & $\begin{array}{l}90.60 \pm \\
0.0577\end{array}$ & $\begin{array}{l}90.50 \pm \\
0.0333 \\
\end{array}$ & $0.2 \mathrm{~g}$ & $\begin{array}{l}92.73 \pm \\
0.7172 \\
\end{array}$ & $\begin{array}{l}92.43 \pm \\
0.5563 \\
\end{array}$ & $0.2 \mathrm{~g}$ & $\begin{array}{l}95.40 \pm \\
0.0577\end{array}$ & $\begin{array}{l}95.51 \pm \\
0.0677\end{array}$ \\
\hline $\begin{array}{l}\text { Sample } \\
\text { volume }\end{array}$ & $25 \mathrm{~mL}$ & $\begin{array}{l}90.60 \pm \\
0.0537\end{array}$ & $\begin{array}{l}90.71 \pm \\
0.0577\end{array}$ & $25 \mathrm{~mL}$ & $\begin{array}{l}92.60 \pm \\
0.0577\end{array}$ & $\begin{array}{l}92.50 \pm \\
0.0577\end{array}$ & $25 \mathrm{~mL}$ & $\begin{array}{l}95.60 \pm \\
0.0577\end{array}$ & $\begin{array}{l}95.56 \pm \\
0.0577\end{array}$ \\
\hline $\begin{array}{l}\text { Tempera- } \\
\text { ture }\end{array}$ & $\begin{array}{c}\text { Exothermic } \\
30^{\circ} \mathrm{C}\end{array}$ & $\begin{array}{l}90.60 \pm \\
0.0577\end{array}$ & $\begin{array}{l}90.60 \pm \\
0.0447\end{array}$ & $\begin{array}{c}\text { Exothermic } \\
30^{\circ} \mathrm{C}\end{array}$ & $\begin{array}{l}92.25 \pm \\
0.0088\end{array}$ & $\begin{array}{l}92.26 \pm \\
0.0077\end{array}$ & $\begin{array}{c}\text { Exothermic } \\
30^{\circ} \mathrm{C}\end{array}$ & $\begin{array}{l}95.60 \pm \\
0.0577\end{array}$ & $\begin{array}{l}95.39 \pm \\
0.0577\end{array}$ \\
\hline
\end{tabular}

The desorption percentages are gradually increased till equilibrium is reached after $25 \mathrm{~min}$ in case of the crude WMP powder, while the powders modified with lactic acid and tri sodium citrate show equilibrium after $30 \mathrm{~min}$. A desorption value of $87 \%$ has been recorded for the unmodified WMP powder, $92.5 \%$ for the tri sodium citrate modified form and $89 \%$ for lactic acid one (Figure 14, Table 9).

\section{Conclusion}

Water melon peels powder (WMP) and its modified forms proved to be potential bio sorbents for the removal of iron and other co present heavy metals from aqueous solutions, being available low-cost material. The proposed adsorbents were applied on real water samples. The adsorption process is best described by the Langmuir and Freundlich isotherm models. Results of desorption investigations also, assured the possibility to regenerate and reuse the bio sorbents once again.

\section{References}

1. Adekola FA, Hodonou DSS, Adegoke HI (2016) Thermodynamic and kinetic studies of biosorption of iron and manganese from aqueous medium using rice husk ash. Appl Water Sci 6(4): 319-330. 
2. Wasiu MO, Ayodele OE, Ayodele TI, Oluremi OI, Ogundele KT, et al (2016) Heavy metal contamination in stream water and sediments of gold mining areas of South Western Nigeria. African J Environ Sci Tech 10(5): 150-161.

3. Verlicchi P (2018) Hospital Wastewaters, Characteristics, Management, Treatment and Environmental Risks. The Handbook of Environmental Chemistry p. 60.

4. Krishnan KA, Sreejalekshmi KG, Baiju RS (2011) Nickel (II) adsorption onto biomass based activated carbon obtained from sugarcane bagasse pith. Bioresour Technol 102(22): 10239-10247.

5. Kula I, Uğurlu M, Karaoğlu H, Celik A (2008) Adsorption of Cd (II) ions from aqueous solutions using activated carbon prepared from olive stone by $\mathrm{ZnCl}_{2}$ activation. Bioresour Technol 99(3): 492-501.

6. Ramakrishna G (2017) Biosorption of lead by Bacillus licheniformis isolated from e-waste landfill, Hyderabad, Telangana, India. Inter J Bioassays 6: 5240-5244.

7. Tripathi A, Ranjan MR (2015) Heavy Metal Removal from Wastewater Using Low Cost Adsorbents. J Bioremed Biodeg 6(6): 315-320.

8. Garba ZN, Ugbaga NI, Abdullahi AK (2016) Evaluation of optimum adsorption conditions for $\mathrm{Ni}$ (II) and Cd (II) removal from aqueous solution by modified plantain peels (MPP). J Basic \& Appl Sci 5(2) 170-179.

9. Alslaibi TM, Abustan I, Ahmad MA, Abu Foul A (2013) Cadmium removal from aqueous solution using microwaved olive stone activated carbon. J Environ Chem Eng 1(3): 589-599.

10. Fu F, Wang Q (2011) Removal of heavy metal ions from wastewater: A review. J Environm Manag 92(3): 407-418.

11. Avalude S, Tella AC (2016) Removal of hexavalent chromium from aqueous solutions by adsorption on modified groundnut hull. J Basic \& Appl Sci (BJBAS) 159: 377-388

12. Mekatel El H, Amokrane S, Aid A, Nibou D, Trari M (2015) Adsorption of methyl orange on nanoparticles of a synthetic zeolite. Comptes rendus - Chimie 18(3): 336-344.

13. Shirzad Siboni M, Khataee A, Hassani A, Karaca S (2015) Preparation, characterization and application of a CTAB-modified nanoclay for the adsorption of an herbicide from aqueous solutions: kinetic and equilibrium studies. Comptes rendus - Chimie 18(2): 204-214.

14. Acharya J, Kumar U, Rafi PM (2018) Removal of Heavy Metal Ions from Wastewater by Chemically Modified Agricultural Waste Material as Potential Adsorbent-A Review. Int J Curr Eng Techno 8(3): 526-530.

15. Abdel Tawwab M, El-Sayed GO, Shady SHH (2017) Capability of some agricultural wastes for removing some heavy metals from polluted water stocked in combination with Nile tilapia, Oreochromis niloticus (L.). Int Aquat Res 9(2): 153-160

16. Negm N, Hefni HHH, Abd Elaal AA (2018) Assessment of Agricultural Wastes as Biosorbents for Heavy Metal Ions Removal from Wastewater. In book: Surfactants in Tribology 5: 466-487.

17. Qu J, Meng X, Jiang X, You H, Wang P, et al. (2018) Enhanced removal of Cd (II) from water using sulfur-functionalized rice husk: Characterization, adsorptive performance and mechanism exploration. J of Cleaner Production 183: 880-886.

18. Munagapati VS, Yarramuthi V, Nadavala SK, Alla SR, Abburi K (2010) Biosorption of $\mathrm{Cu}$ (II), Cd (II) and $\mathrm{Pb}$ (II) by Acacia leucocephala bark powder: Kinetics, equilibrium and thermodynamics. Chem Eng 157(2-3): 357-365.

19. Reddy DHK, Ramana DKV, Seshaiah K, Reddy AVR (2011) Biosorption of Ni (II) from aqueous phase by Moringa oleifera bark, a low cost biosorbent. Desalination 268: 150-157
20. López-Mesas M, Navarrete ER, Carrillo F, Palet C (2011) Bioseparation of $\mathrm{Pb}$ (II) and Cd (II) from aqueous solution using cork waste biomass. Modeling and optimization of the parameters of the biosorption step. Chem Eng J 174(1): 9-17.

21. Ding Y, Jing D, Gong H, Zhou L, Yang X (2012) Biosorption of aquatic cadmium (II) by unmodified rice straw. Bioresour Technol 114: 20-25.

22. Witek Krowiak A, Szafran RG, Modelski S (2011) Biosorption of heavy metals from aqueous solutions onto peanut shell as a low-cost biosorbent. Desalination 265(1-3): 126-134.

23. Alomá I, Martín Lara MA, Rodríguez IL, Blázquez G, Calero M (2012) Removal of nickel (II) ions from aqueous solutions by biosorption on sugarcane bagasse. J Taiwan Inst Chem Eng 43(2): 275-281.

24.Witek Krowiak A (2012) Analysis of temperature-dependent biosorption of $\mathrm{Cu}^{2+}$ ions on sunflower hulls: Kinetics, equilibrium and mechanism of the process. Chem Eng J 192: 13-20.

25. Hossain MA, Ngo HH, Guo WS, Setiadi T (2012) Adsorption and desorption of copper (II) ions onto garden grass. Bioresour Technol 121: 386-395

26. Martins AE, Pereira MS, Jorgetto AO, Martines MAU, Silva RIV, et al. (2013) The reactive surface of Castor leaf [Ricinuscommunis L.] powder as a green adsorbent for the removal of heavy metals from natural river water. Appl Surf Sci 276: 24- 30.

27. Iqbal M, Saeed A, Edyvean RGJ (2013) Bioremoval of antimony (III) from contaminated water using several plant wastes: Optimization of batch and dynamic flow conditions for sorption by green bean husk (Vignaradiata). Chem Eng J 225: 192-201.

28. Farhan AM, Al-Dujaili AH, Awwad AM (2013) Equilibrium and kinetic studies of cadmium (II) and lead (II) ions biosorption onto Ficuscarcia leaves. J Ind Chem 4: 24-31.

29. Areco MM, Saleh-Medina L, Trinelli MA, Marco-Brown JL, Dos Santos Afonso M (2013) Adsorption of $\mathrm{Cu}$ (II), Zn (II), Cd (II) and $\mathrm{Pb}$ (II) by dead Avenafatua biomass and the effect of these metals on their growth. Colloids Surf. B. Biointerfaces 110: 305-312.

30. Al-Azabi K, Al-Marog S, Abukrain A, Sulyman M (2018) Equilibrium, Isotherm Studies of Dye Adsorption onto Orange Peel Powder. Chem Res J 3(1): 45-59.

31. Bharat S, Manchanda D (2017) Efficient bio adsorbents for removal of heavy metals from water: A review. Int J Chem Studies 5(4): 16911694

32. Jain N (2015) Removal of heavy metal b using different fruit peels vegetable peels and organic waste - A review. Int J Adv Res 3(11): 916920 .

33. Taralgatti PD (2016) Removal of copper from waste water by using potato and banana peels as bio-adsorbent. Int J Sci Eng \& Techn Res (IJSETR) 5(10): 3038-3040.

34. Torab Mostaedi M, Asadollahzadeh M, Hemmati A, Khosravi A (2013) Equilibrium, kinetic, and thermodynamic studies for biosorption of cadmium and nickel on grapefruit peel. J Taiwan Inst Chem Eng 44: 295-302.

35. Kelly Vargas K, Cerro Lopez M, Reyna Tellez S, Bandala ER, Sanchez Salas JL (2012) Biosorption of heavy metals in polluted water, using different waste fruit cortex. J Phys Chem Earth 37: 26-29.

36. Demirbas A (2008) Heavy metal adsorption onto agro-based waste materials: a review. J Hazard Mater 157(2-3): 220-229.

37. Abdel Ghani N, Hefny M, El Chaghaby GAF (2007) Removal of lead from aqueous solution using low cost abundantly available adsorbents. J Environ Sci 4(1): 67-73. 
38. Hassouna MEM, Elbably MA, Marzouk MA, El Maghraby AH (2017) Evaluation of Green Clover Leaves as Green and Economic Sorbent for Removal of High Levels of Iron from Different Water Sources. Int J Environ Sci Nat Res 1(2): 555559.

39. https://en.wikipedia.org/wiki/Watermelon

40. Vidhyadevi TA, Murugesan A, Kalaivani SS, Premkumar MP, Vinoth kumar V, et al. (2014) Evaluation of equilibrium, kinetic, and thermodynamic parameters for adsorption of $\mathrm{Cd}^{2+}$ ion and methyl red dye onto amorphous poly(azomethinethioamide) resin. Desalination Water Treat 52(19-21): 3477-3488.

41. Kalaivani SS, Vidhyadevi T, Murugesana A, Thiruvengadaravi KV, Anuradha D, et al. (2014) The use of new modified poly (acrylamide) chelating resin with pendent benzothiazole groups containing donor atoms in the removal of heavy metal ions from aqueous solutions. Water Resources and Industry 5: 21-35.

42. Kumar D, Gaur JP (2011) Metal biosorption by two cyanobacterial mats in relation to $\mathrm{pH}$, biomass concentration, pretreatment and reuse. Bioresour Technol 102(3): 2529-2535.
43. Dang VBH, Doan HD, Dang Vu T, Lohi A (2009) Equilibrium and kinetics of biosorption of cadmium (II) and copper (II) ions by wheat straw. Bioresour Technol 100(1): 211-219.

44. Krishnani KK, Xiaoguang M, Christodoulatos C, Boddu VM (2008) Biosorption mechanism of nine different heavy metals onto biomatrix from rice husk. J Hazard Mater 153(3): 1222-1234.

45. Gupta VK, Rastogi A, Nayak A (2010) Biosorption of nickel onto treated alga (Oedogoniumhatei): Application of isotherm and kinetic models. J Colloid Interface Sci 342(2): 533-539.

46. Dehghani MH, Sanaei D, Ali I, Bhatnagar A (2016) Removal of chromium (VI) from aqueous solution using treated waste newspaper as a lowcost adsorbent: kinetic modeling and isotherm studies. J Mol Liquids 215: 671-679. 